\title{
Digital historical research and the repositioning of Africa in knowledge production
}

\author{
Bernard Kusena and Miriam Zhou
}

Abstract: Africa's historical knowledge production has exhibited promising signs of progress, particularly in strengthening the continent's weak link in the global knowledge network. While such knowledge ought to intersect and interact with other bodies of knowledge from the rest of the world, the terrain is shifting quickly due to changing historical circumstances. This study deploys a case study of Zimbabwe to illustrate how the slow digital transformation in historical research has hindered efforts to confront the overarching question of constrained knowledge production in Africa. The over-reliance of economic history, archaeology, or history on the use of centralised state archives poses complex methodological challenges, particularly for the study of the recent African past. Despite the advantages offered by digital humanities, the research options for these disciplines continue to shrink in the face of serious discomfort by academics in embracing digital sources of data that complement paper-based archival evidence and re-gear the continent's research performance. The article stresses that the sources of historical data, particularly on Africa's post-colonial history, can be found in digital form outside state repositories.

Keywords: Digital humanities, archival evidence, repositories, knowledge production, digital historical research.

(C) The author(s) 2021. This is an open access article licensed under a

Creative Commons Attribution-NonCommercial-NoDerivs 4.0 Unported License 


\section{Introduction}

Although traditional historians and educationists who are cautious about the use of methodologies in historical fields may pose a debate regarding the quality of evidence produced by text messages and other digital channels, there is a growing consensus on the need to tap into the wealth of digitised data generated through communication gadgets by people in their everyday lives. This study explores the contribution that could be made by embracing digital evidence as a tool for knowledge production visà-vis archival material in view of growing calls to reposition Africa in knowledge production. It opens up new lines of inquiry on how to repurpose digital evidence towards sustained historical research. The article deploys political economy theory to demonstrate the relationship between political policy that demands digitalised evidence-based research and the availability of economic resources required for the procurement by the wider population of mobile phones and recording infrastructure that capture lived experiences in communities even far afield.

\section{Background}

Following the opening up of airwaves to private players in 1998 and Strive Masiyiwa's battle with the Zimbabwean courts to enter the telecoms business, the proliferation of wireless communication infrastructure, such as mobile phones, has brought exciting opportunities to Zimbabwean researchers. The state-owned parastatal NetOne, which had previously enjoyed a monopoly in this niche area of wireless communication, proved incapable of meeting demand for the service; hence the entry of private players like Telecel Zimbabwe and Econet Wireless. After successfully lobbying the country's regulatory authority for admission into the information transfer business, Telecel and Econet expanded their network coverage to include previously marginalised areas both within and outside urban centres (Robb et al. 2017).

The three mobile network operators, Econet Wireless, NetOne, and Telecel Zimbabwe, continued to invest in network upgrades to support data services. This has opened up new opportunities for people in different localities to embrace the use of cell phones. Thereafter, the expanding use of cell phones began to impact hugely on access to digitised data, which researchers have found more easily accessible than traditional archival evidence due to bureaucracy and other legal complexities. Although a lot of vigilance and scrutiny in verifying the authenticity of data posted through modern platforms are required, the mere availability of such data has been a milestone because, traditionally, it required long periods of waiting for such material to be released by the archives. 
Against this background, this article illuminates the grey areas surrounding access to electronic information. For instance, while digitised data is a welcome source of critical evidence, it comes with a huge cost. Many rural people, especially ordinary people, cannot afford the ever-spiralling costs of electronic gadgets, yet this is where historical data can also be retrieved. Handsets with built-in mechanisms that provide functions like WhatsApp, the internet, Short Message Service (SMS), and Twitter (along with data bundles) remain expensive, and even more so when Zimbabwe's economy continues to teeter on the brink of disaster. Apparently, these shortfalls tend to compromise and frustrate the 'history from below' initiative that aims to extract historical data from disadvantaged but data-providing populations.

\section{The traditional approach in data collection}

The most common source of data used by historians in Zimbabwe and many other African countries has been state repositories where after periods extending to 20-25 years, materials are sent for archiving. Traditionally, this paper-based system has been considered the best source of historical evidence. Environmental historians have added their voice to this issue, highlighting that there is growing need to rethink data capture and storage for climate change. For example, Brunet and Jones (2011), have argued that, while traditional archival literature is available in archives, there are benefits to digitalising data on the historical climate in order to help the populace appreciate climate variability and change in the 21 st century.

Analyses have been carried out on exactly what historians' sources are and how they should be approached. The debate has underlined the fundamental question of what history is, and how and why it should be written (Momigliano 1966, Le Goff 1992, Collingwood 1993, Kelly 1998, Ginzburg 2012). Other scholars have also interrogated the term 'archive' itself. Blouin and Rosenberg (2011), for example, have attempted to unpack this term, making the point that what constitutes an archive is not always clear cut. They claim that, although predominantly understood as a formal repository of official records, the concept is often extended to accommodate more diverse documentary residues of the past.

\section{Opportunities and threats in digitalisation}

Digital sources of evidence are not a new phenomenon. They have been created and used by historians in Western nations. They have their own downside. Just as paper archives can be vulnerable to theft and forgery, the bona fide researcher is at the mercy 
of the archivist on whose criteria, knowledge, sensitivity, and skills the researcher depends. 'The Art of the Archive' (2013) has shed light on the pros and cons of the digital research tool. In this regard, digital preservation can be hindered by swift technological changes, so it is important to have secure digital storage. However, the categorisation of an archive assumes less importance once it has been fully digitised. The rapidity of search mechanisms and multiple-point access are enormous benefits in terms of saving time, focusing research, and the revelation of unexpected material.

The contents of recent and contemporary archives themselves are at risk or are not always as rich as they might be: for example, faxes fade. 'The Art of the Archive' (2013) further observes that floppy disks are not eternal. Emails are not always printed out and filed: they have that personally unsigned, detached look that suggests a certain inferiority to a postal communication. A question has been raised by researchers: Who will know what a lightning press on the delete key has wiped from the historical record? In addition, funding constraints can be a hindrance to endeavours to utilise digital historical information. To finalise an archive and place it online is not only costly but is also laborious. Archives are also frequently omitted from the larger strategic planning of institutions. With recent cuts in the arts sector and proposed further cuts to humanities budgets in global settings, the ordering and digitising of archives are less likely to receive financial support.

As the discussion around digitalisation took centre stage, one area of research interest that academics and artists seized upon was family history. Hunter (2007) brought in an interesting angle about photography, an important source of historical data critical to researchers. That article sheds light on ways to recover and improve old photographs using digital tools. For instance, the main forms of deterioration of primary material such as photographs are discolouration, tearing, cracking, water spot damage, or loosening of the emulsion from the celluloid. It is a common problem that, once the information on an old photograph is gone, it can never be recovered. To depend strictly on repositories for such material will not yield positive results, given the nature of deterioration such precious documents can suffer under prolonged periods of storage.

The advent of digitalisation has brought along with it exciting opportunities where the need to utilise computers has become indispensable in the digital era. While far from perfect, computers are a good way of translating old photographic material into a digitised form, which loses some of the information, but preserves what it can in a form which is likely to remain readable for many years to come. Until 2007, the best methods of storage included CDs and DVDs but they have since been overtaken by rapid transformations in information technology. However, whatever the changes may bring, one constant is that it is easier these days to store, reproduce, and publish 
photographs in digital form. Hunter (2007) actually predicted that, in the future, film cameras will be obsolete and only digital imaging will be possible.

Photographs are beautiful, but they also tell a story with historical significance. For this to happen, digitalisation offers greater opportunities for one to clearly add information such as dates, places, names and relationships to photographs and other digital records. Harry (2007) maintains that there are arguments galore about the best method of storing the digital information one has gathered, but is quick to advise that the volatility of technology is one big reason to retain one's original sources. The great thing about digital photography and storage is that computer technology drives the whole world of storage systems and it will always be possible to upgrade digitally stored photographs to the latest medium with no loss of information. Old photographs are a major resource for family historians as they provide not only some historical information, but also historical context.

Contributing to this debate, Svensson (2016) states that digital material includes relatively recent materials, such as archived emails, websites, online fiction, old games, surveillance data, online videos, dance performance sensor data, and live data feeds, all of which can be useful for humanistic inquiry. He is supported by Kominko (2015) who wrote about the British Library's Endangered Archives Programme that was founded to digitise and bring vulnerable documentary materials into the academic domain. The programme belongs to a long tradition of scholarly efforts to find and publish new pieces of historical evidence. Large and often heterogeneous digital materials inform the need for tools and expertise to manage, retrieve, and search data. Analogue tools, systems like concordances, library catalogues, or new kinds of tools should draw more distinctly on the attributes of modern digital technology.

\section{Repositioning Africa: court records as historical evidence in a comparative context}

Historians of various kinds, from environmental, social, and economic to legal, have relied heavily on court records, either in physical or digitised form, to reconstruct stories that affect human relations. A legal scholar, for instance, uses digitised court proceedings to bring out interesting historical issues that affect people in their everyday lives. A critical question to explore is how far historians can agree to use WhatsApp evidence as a source of data on which analyses of historical material can rely. There is a general consensus that it is not reliable. Perhaps one way to look at it is how such evidence is treated in other fields. The area of law is one such realm where litigation progresses through adducing evidence. 
Digital evidence, also called electronic evidence, is either stored or transmitted in digital form, which litigants to court processes can deploy at trial. Key to this process is the question whether or not such information has a high probative value. The evidence should be sufficiently useful to prove important arguments in a trial. In some jurisdictions, a court hearing a matter needs to determine if the evidence is not hearsay, or is authentic, relevant, or admissible.

Riding on this framework, courts in many parts of Africa have begun to accept digital evidence in pursuit of justice. Emerging scholars have dubbed this information era 'a golden age of evidence', citing the variety and volume of digital material that reveals conversations, locations, timelines, photographs, and videos. On the international front, two famous cases thrived on account of digital evidence to uncover the dynamics that ultimately played a key role in the outcome of the cases. The first such case was that of Paul Ceglia vs Mark Zuckerberg which occurred in 2010, involving Paul Ceglia, a wood pellet salesman from Wellsville, New York, and Facebook and Another (that is, Mark Zuckerberg, Facebook's Chief Executive Officer).

The brief facts of the matter are that, in 2003, Ceglia wrote a contract in which he allegedly hired Zuckerberg to undertake computer programming for his company called Street Fax. He claimed that this contract entitled him to a $50 \%$ share of Facebook. Coincidentally, Zuckerberg, then a Harvard student, had responded to an advert published by Ceglia for which he had been paid $\$ 1000$ after completing the work. The turning point of this matter arose when Ceglia then subsequently alleged that he had also made a $\$ 1000$ investment in "The Page Book", prompting him to claim that this was 'seed investment' which actually entitled him to a $50 \%$ share of the company.

In support of this claim, Ceglia's legal team mounted a series of correspondence by email between the two litigants that purportedly showed the 50/50 share agreement. The courts were overwhelmed by the matter to the extent that the application of digital evidence was necessary in order to arrive at a more informed verdict. Thus, the courts allowed Facebook to conduct forensic testing on Ceglia's computer despite the latter's disapproval. It was during this testing process that Facebook found the original contract embedded in the electronic data on Ceglia's hard drive. Although observers had warmed to Ceglia's evidence, the original contract never mentioned Facebook or "The Page Book", but it mentioned his Street Fax Company.

Further to the above revelations, the forensic data showed evidence of the use of six USB devices which, according to court papers, Ceglia had claimed had been lost. There was also a forged contract in one of the folders which Ceglia used to support his claim against the defendants. The unearthing of this crucial evidence further spurred on Facebook's forensic experts to analyse Zuckerberg's email account since his days at Harvard. They found no signs of the email chain Ceglia produced alleging 
an agreement between him and Zuckerberg to share the company 50/50. These combined analyses led to the case against Facebook being dismissed, with Ceglia facing charges of attempting to defraud Facebook of billions of dollars.

The importance of digital evidence to historical research interest is also manifested in the criminal case of People v Garcia and Another 2012, involving the murder of 74-year old Clifford Lambert, a Miami dealer. The co-defendants in this matter, Daniel Garcia and Kaushal Niroula, were on 7 September 2012 convicted of murder after they had stabbed Lambert. The circumstances of the case are that Garcia and Niroula planned to con Lambert using information Garcia had obtained on Lambert, which included his phone number and address. Niroula also called Lambert to pose as an attorney representing the estate of May Department Stores Company heiress, Florence May Schoenborn. Fully aware of Lambert's interests in artwork, Niroula told Lambert that he had inherited some valuable artwork from the Schoenborn estate.

Having set out their plan, the two made arrangements to drive to Lambert's Palm Springs residence, roping in Mike Replogle, a Bay Area attorney. On arrival, two other accomplices, Migual Bustamante and Craig McCarthy, were let in, one of whom stabbed Lambert to death. They proceeded to stuff Lambert's body in his own car, then drove to the desert where they buried the body in order to conceal the evidence. Immediately after commission of this crime, Garcia began to use Lambert's debit card and, along with Niroula, opened a new bank account using Replogle's identity and account information. Posing as Lambert, Replogle gave Russell Manning, a San Francisco art dealer, the power of attorney over Lambert's accounts and estate. They, thus proceeded to transfer upwards of $\$ 200,000$ from Lambert's account to the new account. They transferred other various amounts until Lambert's original account was drained.

When the matter was brought to trial, the prosecution relied on a hired digital forensics researcher, Jonathan Zdziarski, to unearth the scam. Garcia, a self-actor in the trial, was the last of the defendants to be tried, submitting the argument that the police had actually framed him by tampering with his phone, inserting texts on it. It was through digital forensics that the hired expert was able to access Garcia's phone and proved beyond reasonable doubt that police had not tampered with his phone and that the texts revealed an order from him to murder Lambert. His conviction was, thus, based on digital information.

There are initiatives available to researchers to access data. Some companies, such as DigitalSTRATA and others, have tasked themselves with the responsibility to collect, preserve, and analyse all types of data. On their website, ${ }^{1}$ Digital STRATA,

${ }^{1} \mathrm{https}: / /$ www.digital-strata.com 
for instance, have pointed out that they can do digital collections for all platforms, devices, and data types. They are able to manage custodial and non-custodial data sources, computers, servers, mobile devices, USB devices, and cloud (Dropbox, Box, Google Drive, and iCloud) activity. Further to this, the company can provide database, web, wiki, social media, structured and unstructured expertise; onsite, remote, and targeted collections; as well as evidence management, including chain of custody, secure storage, and matter-end destruction. Over and above this, DigitalSTRATA specialises in data forensics, covering a wide range of digital devices, operating systems, and cloud activity. This also includes forensically sound content and metadata preservation; deleted data identification and recovery; smartphone and tablet analysis, Windows Registry, artefact and log file analysis; analyses of calls, chats, web histories, and log files; password and encryption cracking; and cloud activity.

In the African context, the courts are rethinking their position with regards to digital evidence, and for the historian, this is welcome. In East Africa, there has been a proposal for a paperless digital system which ensures that evidence is not lost or tampered with. Already, in Sudan, this system has been introduced through the Court of Justice of the Common Market for Eastern and Southern Africa (COMESA), while it is being piloted in Kenya's Court of Appeal. The paperless system is also being used in civil litigation cases in South Africa. It enables evidence to be uploaded and managed digitally, meaning that it becomes impossible to lose papers or documents without trace. Its advantage is that it does not demand investment in information technology infrastructure because it can simply be switched on as it is cloud-based. It has been dubbed CaseLines. Inasmuch as this system has been welcomed by the courts in pursuit of objectives to eliminate financial and other barriers to justice, historians and other scholars in future can also access this material.

Courts have noted the efficiency brought about by the paperless digital system. Processes such as physical filing have become obsolete, bringing judges and litigants closer to justice. In South Africa, as in COMESA, CaseLines has been hailed as capable of ending the need for paper while also allowing the presentation of digital bundles, including multimedia evidence, in court. Lawyers are able to file applications and evidence in more secure environments, away from their offices, saving on the cost of copying and transporting paper files. At the same time, this cuts the risk of losing or misplacing files. In addition, the system supports pretrial preparation, especially for lawyers supporting clients in different countries.

Digitalisation also offers pretrial tools that enable lawyers to prepare and secure role-validated video-conferencing for virtual hearings. While it is true that the digital system at the COMESA Court, which is based in Khartoum, Sudan, and where twelve judges from each member state sit, offers exciting advantages to lawyers by saving considerable time and cost to file applications and send paper copies of evidence to 
the court, it could be said that other jurisdictions are already enjoying bigger benefits from this system. For instance, CaseLines has delivered paperless hearings for lawyers and courts in the United Kingdom and the United Arab Emirates, with the platform holding over 300,000 cases at any given time.

\section{The COVID-19 archive, its challenges, and the fresh demand for digitalisation}

Even as the world continues to grapple with social distancing and battles the coronavirus (COVID-19) pandemic, academics have been prompted to rethink the use of digital sources in producing historical knowledge. Globally, many countries have already taken tentative steps to ease lockdown measures in order to allow citizens to move freely and revive the economy. As has been noted on various media platforms, people should embrace the 'new normal' brought about by the pandemic. In Zimbabwe, as with the rest of the world, visitors coming into the country are required to submit to a coronavirus test within a prescribed number of hours of departing for the country and present proof of a negative result upon arrival. Affected citizens are required to self-quarantine after arrival.

It is against this background that Zimbabwe faces a huge challenge resulting from the pandemic because its physical archives have been closed as part of efforts to curb the spread of the virus. This is the first and foremost impact of the pandemic on historical research because data for future research is not being captured. The failure to switch to digitalisation is prolonging the problem of data mining using new technology. Yet the experiences associated with ongoing lockdown measures should be recorded in various social media platforms; thus casting COVID-19 as an opportunity for African knowledge production.

Wekesa (2020) raises the question of whether there is a danger of Africa being marginalised in terms of knowledge production and dissemination in this era of coronavirus disruptions. He argues that, even in the absence of the pandemic, the continent's presence on the internet is below that of other regions of the world. To support his view, he analyses web-based evidence guided by an understanding of the heightened role of online material in knowledge production. In searching the internet, he discovered that the term 'Covid-19' produced upwards of six billion results. A further click on the phrase 'virtual conference' brought up results exceeding one billion. For him, these huge figures have obscured many specifics, such as Africa's own direct contribution to the knowledge items being generated. This implies that African research entities need to undertake closer analyses in order to gain a more nuanced picture of the continent's performance in global knowledge production. 
Zimbabwe, however, cannot pass the affordability test. The prohibitive costs of digital tools is stalling progress in the efforts required to harness data from various sources, so most of this data is eventually lost before it has been collected. As people make history, some have shared photographs, messages, and experiences in quarantine centres, all of which material is important for historical analysis. A recent snap survey revealed that some people in remote areas lack sufficient information about events in the country regarding their expected conduct in view of proposed measures. For instance, in Betera Village, Mutare, it has been business as usual, with people still gathering for social events without masks. If this is true of cell phone gadgets, what is the situation with respect to computer and internet connectivity? How can we tap data from these remote communities? This leads to Wekesa's (2020) conclusion that, even without the benefit of an empirical study, we can cautiously claim that Africa-specific knowledge production and dissemination over the internet is far lower than that from other continents.

The Zimbabwean state is being challenged to reframe its perception of digitalisation in the most general terms. There appears to be an apprehension of what digitalisation might cause or not cause on the political front. The failure to support access to information and the blackout of the internet and social media in January 2020 following the disturbances in Harare is enough of a signal to suggest that the state is unwilling to extend these opportunities to the masses. For several weeks, the whole country was disconnected from internet activity as the state sought to contain the violence. From the point of view of historical research, these are the people who make history. Their everyday lives should be captured and recorded, leading to Africa potentially increasing its research output in the foreseeable future.

A further observation is that Africa's underperformance in global knowledge dissemination is not an entirely new development. Global knowledge flows are greatly imbalanced to the detriment of the nations of the Global South. Scholars agree that these inequalities are being reproduced and further institutionalised in the circumstances of COVID-19 (Wekesa 2020). The point of departure is that COVID19-related African knowledge production and dissemination can help redress these imbalances. Although the underperformance problem persisted before the outbreak of this novel virus, the pandemic presents an opportunity to address it.

The main question, though, is how far Africa is willing to invest in digital technology as a means to boost its volumes of research output. Looking at the case of Zimbabwe, there is negligible attention being paid to requests by stakeholders for improved budgets for the information technology ministry. During the years of the Government of National Unity, this ministry made important inroads under the then opposition Minister, Nelson Chamisa, with a target of bringing everyone across the rural and urban divide to connectivity. The short duration of his tenure seems to have 
brought all these energies back down to the then prevailing situation. At the time of writing, the ability of people, even the working class, to purchase appropriate communication infrastructure had diminished. This has partly been a result of insufficient interest by the state in further investment in this area, and partly because of the volatility of the local currency which has brought back conditions of hyperinflation characteristic of the 2008 period.

Historical data abound in the daily communications people make, some of which might form an important database for historical review using appropriate data selection tools in a historical study. Wekesa (2020) echoes this observation, highlighting that there is no doubt that Africans are producing lots of knowledge in their informal conversations as in formal engagements of varying types. This knowledge is being produced daily in villages and urban spaces, by African government officials and businesses, by students and researchers. Thus, there are increasing calls for data collectors to package African knowledge products in ways that are convenient and accessible. In order to leverage the vast amount of source material being produced, research entities should erect strategies that make better use of communication infrastructure and resources.

\section{Conclusion}

The article has demonstrated that it is possible for Africa to increase its output of historical research if academics shift from the current framing which shuns digital data. Indeed, there should be a lot of care in handling data extracted from digital sources. But it is still possible because, by training, historians are capable of identifying and selecting historical facts from past events. Its limitations notwithstanding, there is increasing attention being paid to the use of digitised data that makes contemporary historical research a lot easier to conduct due to readily available evidence. The outbreak of the novel coronavirus has changed the whole research landscape, pushing historians to rethink their apprehension about digital sources of data. In many places, court proceedings are conducted on digital evidence, meaning legal historians can rely on such primary sources in their quest for historical knowledge production.

This article has also highlighted the ethical challenges encountered in the deployment of social media data for historical research. It has raised important ethical questions about the implications to the academic historian of 'exploiting' citizen scientists. On the one hand, it teases the view that these historians should actually acknowledge and thank the citizen scientists in their work. However, on the other hand, there is a need to seek 'consent', especially in situations where there are oral 
interviews or photographs, a fact that resonates with ethical standards in the conduct of research worldwide.

The article has dealt with the question of privacy. Tweets are in the public domain and can be mined easily. However, what about personal WhatsApp messages? Historians ought to secure the consent of the owners of such material to be able to use it for historical writing. In addition to these shortfalls, African historians themselves have no training in using digital or digitised material. Unlike American historians who already have some grounding in these technologies, Africa's universities such as the University of Zimbabwe have no comprehensive programmes offering training in these areas.

\section{References}

Blouin, F.X. Jr. \& Rosenberg, W.G. (2011), Processing the Past: Contesting Authority in History and the Archives (Oxford, Oxford University Press).

Brunet, M. \& Jones, P, (2011), 'Data Rescue Initiatives: Bringing Historical Climate Change Data into the 21st Century', Climate Change, 47(1/2: CR Special, 'Climate Services for Sustainable Development'): 29-40. https://doi.org/10.3354/cr00960

Collingwood, R.G. (1993), The Idea of History (Oxford, Oxford University Press).

Ginzburg, C. (2012), Threads and Traces: True False Fictive (Berkeley CA, University of Columbia Press). https://doi.org/10.1525/9780520949843

Hunter, H. (2007), 'Family History Archiving', North Irish Roots, 18(2): 11-15.

Kelly, D.R (1998), Faces of History: Historical Inquiry from Herodotus to Herder (London, Yale University Press).

Kominko, M. (2015), “Crumb Trails, Threads and Traces: Endangered Archives and History”, From Dust to Digital: Ten Years of the Endangered Archives Programme (Cambridge, Open Book Publishers), xlix-lxviii. https://doi.org/10.11647/OBP.0052.23

Le Goff, J. (1992), History and Memory (New York, Columbia University Press).

Momigliano, A. (1966), Studies in Historiography (New York, Harper and Row).

Robb, G., Tausha, I. \& Vilakazi, T. (2017), 'Competition and Regulation in Zimbabwe's Emerging Mobile Payments Markets', in J. Klaaren, S. Roberts \& I. Valodia (eds) Competition Law and Economic Regulation in Southern Africa: Addressing Market Power in Southern Africa (Johannesburg, Wits University Press), 215-33. https://doi.org/10.18772/22017070909.15

Svensson, P. (2016), 'Introducing the Digital Humanities', in Big Digital Humanities: Imagining a Meeting Place for the Humanities and the Digital (Ann Arbor, MI, University of Michigan Press), 1-35. https://doi.org/10.2307/j.ctv65sx0t.5

'The Art of the Archive' (2013), The Burlington Magazine, 155(1322): 303. 2020. http://www.jstor.org/stable/23395349 [accessed 19 July 2010]

Wekesa, B. (2020), 'Covid-19 As an Opportunity for African Knowledge Production', Africa Portal: https://www. africaportal.org [accessed 15 July 2020] 
Notes about the authors

Miriam Zhou holds a Bachelor of Arts degree in History, Classics and Economic History as well as a Graduate Diploma in Education (History and Religious Studies) from the University of Zimbabwe. In 2017, she taught History at Harare High while on teacher training. This is where she appreciated the need for digital transformation in historical sources. In 2020, she enrolled for a Bachelor of Substantive Law degree with the University of Zimbabwe. Her research interests are in law, education, and community development.

miriamzhou5@gmail.com

Bernard Kusena is a Senior Lecturer and Chairperson of the Department of History Heritage and Knowledge Systems at the University of Zimbabwe. He holds a PhD (Humanities) in History from Rhodes University, South Africa, in which he examined rural food security and livelihoods in Zimbabwe. From the University of Zimbabwe, Dr Kusena holds the following qualifications: MA (African Economic History), Bachelor of Laws Honours (LLBs), and BA (Hons.) in Economic History degrees; Diploma in Education (Secondary), and Executive Certificate in Programme Monitoring and Evaluation. His research interests are in the areas of education, law, and rural development.

bkusena@yahoo.com

To cite the article: Bernard Kusena and Miriam Zhou (2021), 'Digital historical research and the repositioning of Africa in knowledge production', Journal of the British Academy, 9(s1): 243-255.

DOI https://doi.org/10.5871/jba/009s1.243

Journal of the British Academy (ISSN 2052-7217) is published by

The British Academy, 10-11 Carlton House Terrace, London, SW1Y 5AH

www.thebritishacademy.ac.uk 
